\title{
EMPLOYEE PERFORMANCE STUDIES: ANTECEDENTS OF WORK DISCIPLINE, WORK MOTIVATION, AND JOB TRAINING
}

\author{
Jasman Syarifuddin Hasibuan ${ }^{1}$, M. Taufik Lesmana ${ }^{2}$ Ainun Permata Sari ${ }^{3}$ \\ ${ }^{1,2,3}$ Universitas Muhammadiyah Sumatera Utara \\ Email: jasmansarifuddin@umsu.ac.id
}

\begin{abstract}
The purpose of this study was to determine and analyze whether Work Discipline, Work Motivation, and Job Training together (simultaneously) or alone (partial) had an effect on Employee Performance at PT. Telekomunikasi Indonesia Tbk Medan Branch.The approach used in this study is an associative approach. The population and sample in this study were all employees of PT. Telekomunikasi Indonesia Tbk Medan Branch in the Data and Management section totaling 50 people using a saturated sample. The data collection technique in this study used a questionnaire technique (questionnaire). The data analysis technique in this study uses the Classical Assumption Test, Multiple Regression, Hypothesis Testing ( $\mathrm{t}$ Test and F Test), and Coefficient of Determination. Data processing in this study used a computer software program Statistical Package for the Social Sciences (SPSS) version 26.00.The results showed that partially work discipline had a positive and significant effect on employee performance at PT. Telekomunikasi Indonesia Tbk Medan Branch. Partially it is known that motivation has a positive and significant effect on employee performance at PT. Telekomunikasi Indonesia Tbk Medan Branch. Likewise with job training which has a positive and significant impact on employee performance at PT. Telekomunikasi Indonesia Tbk Medan Branch. Meanwhile, simultaneously this research proves that work discipline, work motivation and job training have a positive and significant effect on employee performance at PT. Telekomunikasi Indonesia Tbk Medan Branch.
\end{abstract}

\section{Keywords: Work Discipline, Work Motivation, Job Training, and Employee Performance.}

\section{INTRODUCTION}

One of the factors that affect the level of success of the company is the performance of its employees. Every employee certainly wants to be a part of the company's success, with that employees must continue to improve their performance. Performance is the result of the employee's work based on the abilities it has. One of the efforts to improve employee performance in order to increase work productivity is by having good work discipline, providing motivation from company leaders and other fellow employees to increase morale and providing training to improve employees' abilities and work skills. The progress of the company is not only determined by the work of its employees, but also by the discipline of its employees. Good discipline will help the company achieve its goals. In human resource management discipline is a management action to encourage its members to meet the demands of various jobs. In other words, work discipline is an individual habit in the work environment that forms skills, attitudes, and behavior in every work activity that is carried out voluntarily and continuously. 
In addition to discipline, there is also motivation that can improve employee performance and morale. The thing that is often forgotten by some people is the importance of providing motivation, even though motivation is the driving force for the emergence of enthusiasm at work so as to improve performance. Motivation is giving encouragement to employees in various forms to increase employee morale at work so as to produce maximum performance. With the motivation is expected to provide an increase in employee performance.

To achieve the company's goals required maximum performance of employees. To get employees with maximum performance, companies need to train employees. Training is a way to improve the skills of the workforce by providing training in accordance with their respective fields of work. PT. Telekomunikasi Indonesia is the largest telecommunications company in Indonesia, which is the only state-owned telecommunications company as well as the largest telecommunications and network service provider in Indonesia. PT. Telekomunikasi Indonesia seeks to provide quality and affordable Internet connections to improve the quality of Indonesia's human resources in order to be able to compete at the world level. PT. Telekomunikasi Indonesia offers a variety of products, one of which provides convenience in communicating using WiFi Internet (Indihome). In addition, PT. Telekomunikasi Indonesia also provides cable telephone call services in the form of Voice, and IPTV services for television networks.

Based on the survey results from observations on internship activities that the author did at PT. Telekomunikasi Indonesia, Tbk Medan Branch Data and Management division there are several problems that exist within the company, especially the problem of employee performance that is still not optimal. It can be seen from some employees who are still not disciplined by leaving the office during working hours, smoking and chatting with other employees during working hours. This is because employees feel less motivated at work. Giving motivation that is rarely done is the reason employees do not work optimally. In addition to the lack of motivation, training is also rarely provided by the company so that this causes employees to be confused and ask other employees, especially for technician employees who work in the field.

\section{LITERATURE REVIEW}

\section{Employee performance}

Performance is the result of work done by someone where performance is an assessment of the good or bad quality of employees at work.Sinambela, (2016) states that performance is the willingness of a person or group to carry out an activity and perfect it in accordance with their responsibilities with the expected results. Ratnasari et al., (2020) states that performance is a record of the outcomes resulting from the function of a particular job or activity during a certain period of time. Whereas Adamy, (2016) states that employee performance is how much employees contribute to the organization which includes output quantity, output quality, output period, attendance at work and comparability. From several understandings from experts, it can be concluded that employee performance is the result achieved for contributions in the work and tasks that have been carried out by employees.

\section{Work Discipline}

Discipline is a person's behavior and habits in applying the rules and work procedures that have been determined by the company. Sinambela, (2016) states that work discipline is a 
person's ability to work regularly, diligently continuously and work in accordance with applicable rules without violating the rules that have been set.

Afandi, (2018) states that work discipline is a tool used by managers to change a behavior as well as an effort to increase one's awareness and willingness to obey all company regulations and applicable social norms. Whereas Sutrisno, (2017) states that work discipline is an attitude of willingness and willingness of a person to obey and obey the norms of the regulations that apply around him, good employee discipline will accelerate company goals while declining discipline will become a barrier and slow down the achievement of company goals. From the opinions of the experts above, it can be concluded that work discipline is an attitude and habit of a person in working in an orderly, directed manner, and carrying out applicable regulations without coercion from anyone.

\section{Work motivation}

In the company, it is very necessary to have encouragement to foster enthusiasm in work so as to produce maximum performance. To encourage the growth of enthusiasm in work, motivation is needed. Motivation is a driving tool in increasing employee morale to produce maximum performance so as to achieve company goals to Sinambela, (2016) Motivation is a condition or energy that moves employees who are directed or focused on achieving organizational goals. Whereas Daulay et al., (2017) states that motivation is a reason or impetus for someone to act. And Farida \& Hartono, (2016) stated that motivation is the provision of a driving force that creates one's work enthusiasm so that they want to work together, work effectively and be integrated with all their efforts to achieve satisfaction. Meanwhile, according to Sarinah \& Mardalena, (2017) Motivation is a psychological symptom in the form of a reciprocal encouragement to a person either consciously or unconsciously to take an action with a specific purpose. Meanwhile, Firmansyah \& Mahardika, (2018) In life, motivation has a very important role because motivation is the thing that causes, distributes, and supports human behavior, so that they are willing to work hard and enthusiastically achieve optimal results. Without motivation in a person, it is certain that that person will not move at all from where he is. From several expert opinions regarding motivation, it can be concluded that motivation is the provision of driving force in the form of financial and non-financial support from superiors to subordinates in order to create enthusiasm and superior performance to achieve company goals and objectives.

\section{Work training}

Training is a company's effort to improve employee performance by providing training and development to improve employee capabilities. According to Sinambela, (2016) Training is an activity to improve the ability of employees by allocating a budget as an investment. The same thing is formulated that training is essentially a learning process. Meanwhile, Arianty et al., (2016) stated that training is one of the efforts made by companies to improve the quality of human resources in the world of work. According to Masram \& Mu'ah, (2015) Training (training) is one type of learning process to acquire and improve skills outside the applicable education system in a relatively short time and with methods that prioritize practice over theory. From several opinions regarding training, it can be concluded that training is an effort from the agency/company to improve employee performance by providing training to improve and develop employee knowledge and skills to achieve company goals. 


\section{RESEARCH METHODS}

This research was conducted at PT. Telekomunikasi Indonesia Tbk Medan Branch at the Data and Management section, having its address at Jl. Agarwood No. 1 Terrain. The research time starts from May 2021 to August 2021. The population in this study were all employees of PT. Telekomunikasi Indonesia, Tbk Medan Branch in the Data and Management section, totaling 50 people. The sample in this study were all employees of PT. Telekomunikasi Indonesia, Tbk Medan Branch in the Data and Management section as many as 50 people. List of names of employees of PT. Telekomunikasi Indonesia, Tbk Medan Branch Data and Management division along with the positions and titles as follows:

Tabel 3.1

Rincian Karyawan PT. Telekomunikasi Indonesia, Tbk Branch Medan Data Management

\begin{tabular}{|c|l|c|}
\hline No & \multicolumn{1}{|c|}{ Jabatan } & Jumlah \\
\hline 1 & Team Leader & 2 \\
\hline 2 & Help Desk Logic & 6 \\
\hline 3 & Help Desk Service & 11 \\
\hline 4 & Help Desk Dava & 6 \\
\hline 5 & Help Desk Fallout Data & 10 \\
\hline 6 & Teknisi & 15 \\
\hline & Total & 50 karyawan \\
\hline
\end{tabular}

Source: PT. Telekomunikasi Indonesia Tbk. Branch Medan

\section{RESEARCH RESULTS AND DISCUSSION}

\section{T-Test Results (Partial Test)}

The $\mathrm{t}$ test is used to test how the influence of each independent variable (X) individually (individually) on the dependent variable (Y). In the t-test test, the t-table value is obtained by the formula $\mathrm{dk}=\mathrm{n}-\mathrm{k}$ where $\mathrm{n}$ is the number of respondents and $\mathrm{k}$ is the number of variables, with a significant level of $5 \%(0.05)$.

Tabel 4. 1

Uji Parsial (Uji t)

Coefficients $^{\mathrm{a}}$

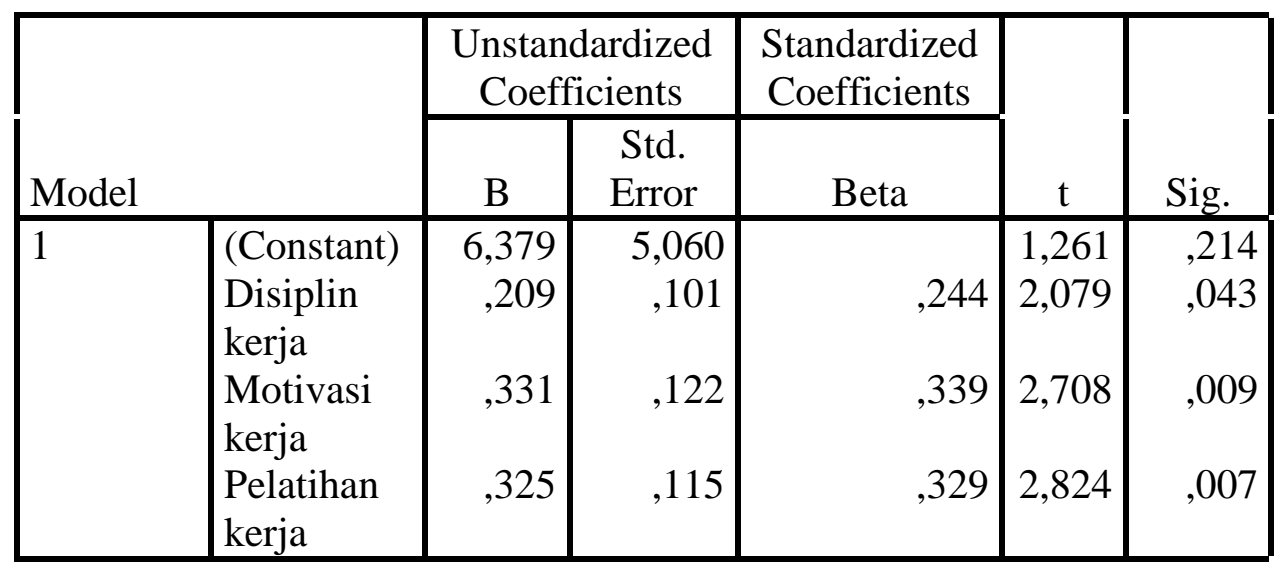

Dependent Variable: Employee performance

Source: Results of data processing SPSS 26, 2021 
The t-test criteria were carried out at the level of $5 \%(0.05)$. Where $\mathrm{n}=50$ and $\mathrm{k}=4$ then the value of $\mathrm{t}$ with the formula: $\mathrm{dk}=\mathrm{n}-\mathrm{k}$ then $50-4=46$ is 2.012 .

\section{The effect of work discipline on employee performance}

The results of the partial test of the effect of Work Discipline (X1) on Employee Performance $(Y)$ obtained $t$ count $>t$ table of $2.079>2.012$ with a significant value of 0.043 $<0.05$ and the coefficient value of the positive variable, it can be concluded that there is a positive and significant influence between work discipline on employee performance at PT. Telekomunikasi Indonesia, Tbk Medan Branch.

\section{The effect of work motivation on employee performance}

The results of the partial test of the effect of Work Motivation (X2) on Employee Performance $(\mathrm{Y})$ obtained $t$ count $>\mathrm{t}$ table of $2.708>2.012$ with a significant value of 0.009 $<0.05$ and a positive variable coefficient value, it can be concluded that there is a positive and significant influence between work motivation and employee performance at PT. Telekomunikasi Indonesia, Tbk Medan Branch.

\section{The effect of job training on employee performance}

The results of the partial test of the effect of Job Training (X3) on Employee Performance (Y) obtained t count $>t$ table of $2.824>2.012$ with a significant value of $0.007<0.05$ and a positive variable coefficient value, it can be concluded that there is a positive and significant influence between training on employee performance at PT. Telekomunikasi Indonesia, Tbk Medan Branch.

\section{F Test Results (Simultaneous Test)}

The $\mathrm{F}$ test is used to determine the effect of all independent variables (X1, X2, and X3) together whether or not it has a significant effect on the dependent variable (Y). In the F test test the value of Fcount is obtained by the formula df $1=k-1$ and df $2=n-k$ where $n$ is the number of respondents and $\mathrm{k}$ is the number of variables, with a significant level of 5\% (0.05).

Tabel 4. 2

Uji Simultan (Uji F)

ANOVA ${ }^{a}$

\begin{tabular}{|ll|r|r|r|c|l|}
\hline Model & Sum of Squares & df & Mean Square & F & Sig. \\
\hline 1 & Regression & 137,134 & 3 & 45,711 & 14,659 &, $000^{\mathrm{b}}$ \\
& Residual & 143,446 & 46 & 3,118 & & \\
\multicolumn{2}{|c|}{ Total } & 280,580 & 49 & & & \\
\hline
\end{tabular}

a. Dependent Variable: Employee performance

b. Predictors: (Constant), Job training, Work discipline, Work

Motivation.

Source: Results of data processing SPSS 26, 2021

To calculate the value of Ftable in accordance with the provisions of the formula df 1 $=\mathrm{k}-1$ and $\mathrm{df} 2=\mathrm{n}-\mathrm{k}$, then $\mathrm{df} 1=4-1=3$ and $\mathrm{df} 2=50-4=46$ so that the Ftable value is 2.81. Based on the table above, it is known that Fcount > Ftable is $14.659>2.81$ with a 
probability value of sig $0.000<0.005$, thus $\mathrm{H} 0$ is rejected. This shows that there is a positive and significant influence between the variables of work discipline, work motivation, and job training simultaneously (simultaneously) on employee performance at PT. Telekomunikasi Indonesia, Tbk Medan Branch.

\section{Coefficient of Determination Test Results}

The coefficient of determination is used to measure the percentage of the influence of the independent variable on the dependent variable. The value of the coefficient of determination is determined by the value of $\mathrm{R}$ Square as can be seen in the following table:

Tabel 4. 3

\section{Uji Koefisien Determinasi}

\begin{tabular}{|l|c|r|r|r|}
\hline Model & R & R Square & $\begin{array}{c}\text { Adjusted R } \\
\text { Square }\end{array}$ & $\begin{array}{c}\text { Std. Error of } \\
\text { the Estimate }\end{array}$ \\
\hline 1 &, $699^{\mathrm{a}}$ &, 489 &, 455 & 1,766 \\
\hline
\end{tabular}

a. Predictors: (Constant), Job training, Work discipline, Work motivation b. Dependent Variable: Employee performance

Source: Results of data processing SPSS 26, 2021

Based on the table above, it can be understood that:

$$
\begin{aligned}
\mathbf{D} & =\mathbf{R}^{2} \times 100 \% \\
& =\mathbf{0 , 4 8 9} \times 100 \% \\
& =48,9 \%
\end{aligned}
$$

The results of data processing in table 4.15 show an $\mathrm{R}$ Square value of 0.489 , this indicates that $48.9 \%$ of employee performance variables (Y) are influenced by work discipline (X1), work motivation (X2), and job training (X3). Or in other words that work discipline, work motivation and job training affect employee performance by $48.9 \%$, while the remaining $51.1 \%$ is influenced by other factors outside of the variables in this study.

\section{DISCUSSION}

\section{The Effect of Work Discipline on Employee Performance}

Based on the results of the partial test (t-test) above regarding the effect of work discipline on employee performance, the value of $t$ count $>t$ table is $2.079>2.012$ with a significant value of $0.043<0.05$ and the coefficient value of the variable is positive, then $\mathrm{H} 0$ is rejected and $\mathrm{Ha}$ is accepted. . So from these results it can be concluded that partially work discipline has a positive and significant effect on employee performance at PT. Telekomunikasi Indonesia Tbk, Medan Branch. This means that employees have realized the importance of work discipline but to improve performance, employees must continue to improve and apply discipline at work. Good employee discipline will accelerate the company's goals while declining discipline will become a barrier and slow down the achievement of company goals. (Sutrisno, 2017).

\section{The Effect of Work Motivation on Employee Performance}


Based on the results of the partial test (t-test) above regarding the effect of work motivation on employee performance, the value of $t$ count $>t$ table is $2.708>2.012$ with a significant value of $0.009<0.05$ and the coefficient value of the variable is positive, then H0 is rejected and $\mathrm{Ha}$ is accepted. . So from these results it can be concluded that partially work motivation has a positive and significant effect on employee performance at PT. Telekomunikasi Indonesia Tbk, Medan Branch. This means that the majority of employees have understood that the better the motivation, the better the performance.

\section{The Effect of Job Training on Employee Performance}

Based on the results of the partial test (t-test) above regarding the effect of work motivation on employee performance, the value of $t$ count $>t$ table is $2.824>2.012$ with a significant value of $0.007<0.05$ and the coefficient value of the variable is positive, then $\mathrm{H} 0$ is rejected and $\mathrm{Ha}$ is accepted. . So from these results it can be concluded that partially job training has a positive and significant effect on employee performance at PT. Telekomunikasi Indonesia Tbk, Medan Branch. This means that the higher the level of training provided, it can improve employee performance at PT. Telekomunikasi Indonesia Tbk, Medan Branch. Conversely, the lower the level of training provided, the lower the employee's performance will be. Training is an effort to improve and increase the ability of employees to work to achieve company goals. Training and performance have a very close relationship because to achieve good performance, it is necessary to have abilities and skills that are the result of training.

\section{The Influence of Work Discipline, Work Motivation, and Job Training on Employee Performance}

Based on the results of the simultaneous test (f-test) regarding the effect of work motivation on employee performance, the value of Fcount > Ftable is 14,659>2.81 with a significant value of $0.000<0.005$ and the coefficient value of the positive variable is then $\mathrm{H} 0$ is rejected and $\mathrm{Ha}$ is accepted. So from these results it can be concluded that simultaneously Work Discipline, Work Motivation, and Job Training have a positive and significant effect on Employee Performance at PT. Telekomunikasi Indonesia Tbk, Medan Branch. This means that the better work discipline, work motivation, and job training, the better employee performance will be. On the other hand, the lower the work discipline, work motivation, and job training, the lower the employee's performance will be. For this reason, companies must always pay attention to the level of employee discipline and provide work motivation and evaluate performance by providing training to improve and develop employee abilities and skills.

\section{CONCLUSION}

Based on the results of research and discussion on the effect of work discipline, work motivation, and job training on the performance of employees of PT. Telekomunikasi Indonesia Tbk, Medan Branch, it can be concluded as follows:

1. Partially (t-test) that work discipline has a positive and significant effect on employee performance at PT. Telekomunikasi Indonesia Tbk, Medan Branch.

2. Partially (t-test) that work motivation has a positive and significant effect on employee performance at PT. Telekomunikasi Indonesia Tbk, Medan Branch. 
3. Partially (t-test) that job training has a positive and significant effect on employee performance at PT. Telekomunikasi Indonesia Tbk, Medan Branch.

4. Simultaneously (f-test) that work discipline, work motivation, and job training have a positive and significant effect on employee performance at PT. Telekomunikasi Indonesia Tbk, Medan Branch.

\section{REFERENCES}

Adamy, M. (2016). Manajemen Sumber Daya Manusia. Unimal Press.

Afandi, A., \& Bahri, S. (2020). Pengaruh Kepemimpinan Motivasi dan Disiplin Kerja Terhadap Kinerja Karyawan. Jurnal Ilmiah Magister Manajemen, 3(2), 235-246.

Afandi, P. (2018). Manajemen Sumber Daya Manusia: Teori, Konsep dan Indikator. Nusa Media.

Agustini, F. (2019). Strategi Manajemen Sumber Daya Manusia. UISU Press.

Ainanur, A., \& Tirtayasa, S. (2018). Pengaruh Budaya Organisasi, Kompetensi dan Motivasi Terhadap Kinerja Karyawan. Maneggio: Jurnal Ilmiah Magister Manajemen, 1(1), 114. https://doi.org/10.30596/maneggio.v1i1.2234

Arda, M. (2017). Pengaruh Kepuasan Kerja dan Disiplin Kerja Terhadap Kinerja Karyawan Pada Bank Rakyat Indonesia Cabang Putri Hijau Medan. Jurnal ilmiah manjemen \& bisnis, 18(1), 45-60.

Arianty, N. (2016). Pengaruh Kepemimpinan dan Disiplin Terhadap Kinerja Karyawan Pada PT Pelindo Cabang Belawam. Jurnal Manajemen Perpajakan, 4(2), 333-429.

Arianty, N., Bahagia, R., Lubis, A. A., \& Siswadi, Y. (2016). Manajemen Sumber Daya Manusia. Perdana Publishing.

Arif, M., Maulana, T., \& Lesmana, M. T. (2020). Pengaruh Disiplin Kerja dan Kemampuan Kerja Terhadap Prestasi Kerja Karyawan. Jurnal Humaniora, 4(1), 106-119. https://doi.org/10.30601/humaniora.v4i1.515

Arif, M., Syaifani, P. E., Siswadi, Y., \& Jufrizen, J. (2019). Effect of Compensation and Discipline on Employee Performance. Proceeding of The 3rd International Conference on Accounting, Business \& Economics (UII-ICABE 2019), 1(2), 263-276.

Astuti, R., \& Sari, I. (2018). Pengaruh Pelatihan dan Kompensasi Terhadap Kinerja Karyawan Pada PT. Kemasindo Cepat Nusantara Medan. Prosiding Seminar Nasional Royal (SENAR) 2018, 1(4) 461-464.

Astuti, R., \& Suhendri. (2019). Pengaruh Kompensasi dan Motivasi Terhadap Kinerja Karyawan Pada PT. Tunas Jaya Utama. Jurnal Manajemen Bisnis Eka Prasetya (MBEP), 5(2), 1-10.

Atijah, \& Bahri, S. (2021). Pengaruh Kepemimpinan, Motivasi Kerja Dan Budaya Kerja Terhadap Kinerja Pegawai Pada Dinas Sosial Kabupaten Labuhanbatu Utara. Jurnal Humaniora, 5(1), 31-45.

Bismala, L., Arianty, N., \& Farida, T. (2016). Perilaku Organisasi Sebuah Pengantar. Lembaga Penelitian dan Penulisan Ilmiah Aqli.

Bukhari, \& Pasaribu, S. E. (2019). Pengaruh Motivasi, Kompetensi, Dan Lingkungan Kerja Terhadap Kinerja. Jurnal Ilmiah Magister Manajemen, 2(1), 89-103.

Daulay, R., Putri, L. P., Astuti, R., \& Arif, M. (2017). Manajemen. Lembaga Penelitian dan Penulisan Ilmiah Aqli.

Farida, U., \& Hartono, S. (2016). Manajemen Sumber Daya Manusia II. Umpo Press.

Farisi, S. (2018). Effect of Training and Emotional Intelligence on Employee Performance. 
International Conference On Global Education VI, 1(1) 1064-1072.

Farisi, S., Irnawati, J., \& Fahmi, M. (2020). Pengaruh Motivasi dan Disiplin Kerja Terhadap

Kinerja Karyawan. Jurnal Humaniora, 4(1), 15-33.

Firmansyah, M. A., \& Mahardika, B. (2018). Pengantar Manajemen. Deepublish.

Harahap, S. F., \& Tirtayasa, S. (2020). Pengaruh Motivasi, Disiplin, Dan Kepuasan Kerja

Terhadap Kinerja Karyawan Di PT. Angkasa Pura II (Persero) Kantor Cabang

Kualanamu. Jurnal Ilmiah Magister Manajemen, 3(1), 120-135.

Haryono, S. (2018). Manajemen Kinerja SDM. Luxima Metro Media.

Hasibuan, Jasman Sarippudin, \& Silvya, B. (2019). Disiplin Kerja dan Motivasi Terhadap

Kinerja Karyawan. Inovasi Prodik Penelitian Pengabdian Masyarakat \& Tantangan Era Revolusi Industri 4.0, 2(1), 134-147.

Hasibuan, Jasman Saripuddin, \& Handayani, R. (2017). Pengaruh Disiplin dan Motivasi Terhadap Kinerja Karyawan Pada PT. Kemasindo Cepat Nusantara Medan. Kumpulan Jurnal Dosen Universitas Muhamamdiyah Sumatera Utara, 1(2), 418-428.

Hasibuan, M. (2016). Manajemen Sumber Daya Manusia Edisi Revisi. Bumi Aksara.

Hasibuan, S. M., \& Bahri, S. (2018). Pengaruh Kepemimpinan , Lingkungan Kerja dan Motivasi Kerja Terhadap Kinerja. Jurnal Ilmiah Magister Manajemen, 1(1), 71-80.

Hasyim, \& Pasaribu, F. (2021). Pengaruh Iklim Organisasi, Kompetensi, dan Disiplin Kerja Terhadap Kinerja Pegawai pada Kantor Samsat Labuhan Batu Utara. Jurnal Humaniora, 5(1), 54-63.

Hendra. (2020). Pengaruh Budaya Organisasi, Pelatihan Dan Motivasi Terhadap Kinerja Karyawan Pada Universitas Tjut Nyak Dhien Medan. Jurnal Ilmiah Magister Manajemen, 3(1), 1-12.

Jufrizen, J. (2017). Pengaruh Kemampuan dan Motivasi terhadap Kinerja Perawat: Studi pada Rumah Sakit Umum Madani Medan. Jurnal Riset Sains Manajemen, 1(1), 27-34.

Jufrizen, J., \& Hadi, F. P. (2021). Pengaruh Fasilitas Kerja dan Disiplin Kerja Terhadap Kinerja Karyawan Melalui Motivasi Kerja. Jurnal Sains Manajemen, 7(1), 35-54. https://doi.org/10.30656/sm.v7i1.2277

Jufrizen, J. (2018). Peran Motivasi Kerja Dalam Memoderasi Pengaruh Kompensasi Dan Disiplin Kerja Terhadap Kinerja Karyawan. The National Conferences Management and Business (NCMAB) 2018, 1(1) 405-424.

Jufrizen, J, Farisi, S., Azhar, M. E., \& Daulay, R. (2020). Model Empiris Organizational Citizenship Behavior Dan Kinerja Dosen Perguruan Tinggi Swasta Di Medan. EKUITAS (Jurnal Ekonomi dan Keuangan), 4(2), 145-165.

Jufrizen, J, \& Pulungan, D. R. (2017). Implementation of Incentive and Career Development of Performance with Motivation as an Intervening Variable. Proceedings of AICS-Social Sciences, 18(20), 441-446.

Juliandi, A., Irfan, \& Manurung, S. (2014). Metodologi Penelitian Bisnis Konsep dan Aplikasi. UMSU Press.

Kasmir. (2016). Manajemen Sumber Daya Manusia: Teori Dan Praktik. RajaGrafindo Persada.

Kumara, I. W. S. K., \& Utama, I. W. M. (2016). Pengaruh Pelatihan Terhadap Kinerja Karyawan Dengan Mediasi Kepemimpinan Pada Hotel Satriya Cottages Kuta-Bali. EJurnal Manajemen Unud, 5(3), 1399-1428. 
Lesmana, M. T., \& Prayogi, M. A. (2021). The Influence of Leadership Style and Motivation on the Performance of Employees. Proceedings of the Conference on International Issues in Business and Economics Research (CIIBER 2019), 1(1), 122-127.

Lesmana, M. T., Prayogi, M. A., \& Siregar, L. H. (2019). Pengaruh Kompetensi Dan Disiplin Kerja Terhadap Kinerja Pegawai. 1(1), 665-669.

Mangkunegara, A.Anwar Prabu. (2017). Manajemen Sumber Daya Manusia Perusahaan (Cetakan Kesebelas). PT.Remaja Rosdakarya.

Mangkunegara, AA Anwar Prabu. (2013). Manajemen Sumber Daya Manusia Perusahaan (Bandung). PT Remaja Rosdakarya.

Marjaya, I., \& Pasaribu, F. (2019). Pengaruh Kepemimpinan, Motivasi, Dan Pelatihan Terhadap Kinerja Pegawai. Maneggio: Jurnal Ilmiah Magister Manajemen, 2(1), 129147. https://doi.org/10.30596/maneggio.v2i1.3650

Marwansyah. (2014). Manajemen Sumber Daya Manusia Edisi Kedua. Alfabeta.

Masram, \& Mu'ah. (2015). Manajemen Sumber Daya Manusia. Zifatama Publisher.

Mutholib. (2019). Pengaruh Pelatihan Kerja dan Kompensasi Finansial Terhadap Kinerja. Jurnal Pendidikan Akuntansi, 2(3), 14-20. https://doi.org/10.30596/liabilities.v2i3.3993

Nasution, A. E., \& Lesmana, M. T. (2018). Pengaruh Disiplin Kerja Dan Pelatihan Terhadap Kinerja Karyawan PT Hermes Realty Indonesia. Jurnal Manajemen Dan Akuntansi, $1(1), 1-15$.

Nasution, S. N., \& Pasaribu, S. E. (2020). Pengaruh Pengawasan, Motivasi dan Disiplin Terhadap Kinerja Guru pada Yayasan Pendidikan Islam Terpadu Kuntum Bumi Rantauprapat. Jurnal Ilmiah Magister Manajemen, 3(1), 75-91.

Ratnasari, S. L., L Saulina, B., \& Tanjung, R. (2021). Pengaruh Peranan Sumber Daya Manusia, Pelatihan, Dan Disiplin Kerja Terhadap Kinerja Karyawan Pada PT. EMI Internasional. Jenius, 4(2), 153-163.

Ratnasari, S. L., Nasrul, H. W., Nurdin, I., Susilowati, Y., \& Susanti, E. N. (2020). Manajemen Kinerja Karyawan. Forum Pemuda Aswaja.

Sahangggamu, P. M., \& Mandey, S. L. (2014). Pengaruh Pelatihan Kerja, Motivasi, dan Disiplin Kerja Terhadap Kinerja Karyawan Pada PT. Bank Perkreditan Rakyat Dana Raya. Jurnal EMBA, 2(4), 514-523.

Santoso, S. (2019). Pengaruh Pelatihan, Disiplin Kerja, dan Motivasi Terhadap Kinerja Karyawan Lembaga Keuangan. Jurnal Education and Economics (JEE), 2(4), 619-632.

Sarinah, \& Mardalena. (2017). Pengantar Manajemen. Deepublish.

Sedarmayanti. (2017). Manajemen Sumber Daya Manusia. Refika Aditama.

Sembiring, M., Jufrizen, \& Tanjung, H. (2021). Efek Mediasi Kepuasan Kerja pada Pengaruh Motivasi Dan Kemampuan Kerja Terhadap Kinerja Pegawai. Jurnal Ilmiah Magister Manajemen, 4(1), 131-144.

Sinambela, L. P. (2016). Manajemen Sumber Daya Manusia. Bumi Aksara.

Siswadi, Y. (2017). Pengaruh Pelatihan Dan Disiplin Terhadap Produktivitas Kerja Karyawan Padapt. Jasa Marga Cabang (Belmera) Medan. Jurnal Ilmiah Manajemen dan Bisnis, 17(01), 124-137.

Siswanto. (2015). Pengantar Manajemen. Bumi Aksara.

Sugiyono. (2013). Metode Penelitian Kuantitatif Kualitatif Dan R\&D. Alfabeta.

Sugiyono. (2015). Metode Penelitian Pendidikan Pendekatan Kuantitatif, Kualitatif, dan $R \& D$. Alfabeta.

Suhariadi, F. (2013). Manajemen Sumber Daya Manusia Dalam Pendekatan Teoritis-Praktis. 
Airlangga University Press.

Sunyoto, D. (2013). Manajemen Sumber Daya Manusia. Center Of Academic Publishing Service.

Sutrisno, E. (2017). Manejemen Sumber Daya Manusia (Edisi Ke-9). Kencana Prenadiamedia Group.

Syafri, W., \& Alwi. (2014). Manajemen Sumber Daya Manusia Dalam Organisasi Publik. IPDN Press.

Tanjung, H., \& Elizar. (2018). Pengaruh Pelatihan , Kompetensi , Lingkungan Kerja terhadap

Kinerja Pegawai Penanggulangan Bencana Daerah Kabupaten Deli Serdang. Jurnal Ilmiah Magister Manajemen, 1(1), 46-58.

Tanjung, H., Hidayat, T., \& Juliandi, A. (2020). Motivasi Kerja, Budaya Organisasi dan Kompetensi terhadap Kinerja Guru Pada SMK Muhammadiyah 3 Aek Kanopan Taufik. jurnah manajemen bisinis, 17(2), 189-206.

Tupti, Z., \& Arif, M. (2020). The Influence Of Discipline And Motivation On Employee Performance. International Journal of Economic, Technology and Social Sciences (Injects), 1(1), 61-69.

Utami, E., \& Fauziah, F. (2020). Pengaruh Disiplin Kerja, Motivasi Kerja, Dan Pelatihan Kerja Terhadap Kinerja Pegawai Lembaga Penyiaran Publik Televisi Republik Indonesia Stasiun Kalimantan Timur. Change Agent For Management Journal (CAM), 4(2), 73-84.

Yusnandar, W., Nefri, R., \& Siregar, S. (2020). Pengaruh Disiplin Kerja Dan Pelatihan Terhadap Kinerja Karyawan Dengan Budaya Organisasi Sebagai Variabel Moderasi Pada Rumah Sakit Milik Pemerintah di Kota Medan. Jurnal Humaniora, 4(1), 61-72. 
Employee Performance Studies: Antecedents of Work Discipline, Work Motivation, and Job Training Jasman Syarifuddin Hasibuan, M. Taufik Lesmana, Ainun Permata Sari 